University of Nebraska - Lincoln

DigitalCommons@University of Nebraska - Lincoln

\title{
Particle Size Effects on the Quality of Flour Tortillas Enriched with Whole Grain Waxy Barley
}

\author{
Naruemon Prasopsunwattana \\ California State Polytechnic University - Pomona \\ Marfa Botero Omary \\ California State Polytechnic University - Pomona, mboteroomary@csupomona.edu \\ Elizabeth A. Arndt \\ ConAgra Foods Inc \\ Peter H. Cooke \\ USDA-ARS/ERRC \\ Rolando A. Flores \\ University of Nebraska-Lincoln, agdean@nmsu.edu \\ See next page for additional authors
}

Follow this and additional works at: https://digitalcommons.unl.edu/usdaarsfacpub

Part of the Agricultural Science Commons

Prasopsunwattana, Naruemon; Omary, Marfa Botero; Arndt, Elizabeth A.; Cooke, Peter H.; Flores, Rolando A.; Yokoyama, Wallace; Toma, Ayako; Chongcham, Sutida; and Lee, Sylvia P., "Particle Size Effects on the Quality of Flour Tortillas Enriched with Whole Grain Waxy Barley" (2009). Publications from USDA-ARS / UNL Faculty. 903.

https://digitalcommons.unl.edu/usdaarsfacpub/903

This Article is brought to you for free and open access by the U.S. Department of Agriculture: Agricultural Research Service, Lincoln, Nebraska at DigitalCommons@University of Nebraska - Lincoln. It has been accepted for inclusion in Publications from USDA-ARS / UNL Faculty by an authorized administrator of DigitalCommons@University of Nebraska - Lincoln. 


\section{Authors}

Naruemon Prasopsunwattana, Marfa Botero Omary, Elizabeth A. Arndt, Peter H. Cooke, Rolando A. Flores, Wallace Yokoyama, Ayako Toma, Sutida Chongcham, and Sylvia P. Lee 


\title{
Particle Size Effects on the Quality of Flour Tortillas Enriched with Whole Grain Waxy Barley
}

\author{
Naruemon Prasopsunwattana, ${ }^{1}$ María Botero Omary, ${ }^{1,2}$ Elizabeth A. Arndt, ${ }^{3}$ Peter H. Cooke, ${ }^{4}$ Rolando A. Flores, ${ }^{5}$ \\ Wallace Yokoyama, ${ }^{6}$ Ayako Toma, ${ }^{1}$ Sutida Chongcham, ${ }^{1}$ and Sylvia P. Lee ${ }^{1}$
}

ABSTRACT

Cereal Chem. 86(4):439-451

\begin{abstract}
Wheat tortillas were enriched with whole barley flour (WBF) of different particle sizes including $237 \mu \mathrm{m}$ (regular [R]), $131 \mu \mathrm{m}$ (intermediate [IM|), and $68 \mu \mathrm{m}$ (microground [MG]). Topographical and fluorescent microstructure images of flours, doughs, and tortillas were examined. Flours and tortillas were analyzed for color, protein, ash, starch, moisture, and $\beta$-glucan content. Farinograph testing was conducted on the flour blends. Water activity and texture analyses of tortillas were conducted. A 9-point hedonic scale was used by 95 untrained panelists to evaluate tortilla appearance, color, flavor, texture, and overall acceptability. Two commercial products (CP) were included in some analyses. As WBF
\end{abstract}

particle size decreased, color was lighter; protein, moisture content and mixing stability decreased; ash, starch content, water absorption and farinograph peak time increased; and $\beta$-glucan content was constant. WBF tortillas were darker than the control (C), while IM and MG tortillas had lower peak forces than $\mathrm{C}$. No flavor differences were reported among $\mathrm{C}, \mathrm{R}$, and $\mathrm{MG}$ tortillas but higher scores were given to both $\mathrm{CP}$ in all attributes tested. Tortillas made with the largest WBF particle size (R) were the most similar in protein content, texture and flavor when compared with $\mathrm{C}$ tortillas made with refined bread flour
Due to insufficient intake of whole grains, fruits, and vegetables, most Americans are failing to consume the recommended amounts of total dietary fiber (TDF) per day (Williams et al 2002). According to data reported by Arndt (2006), the average fiber intake in the U.S. is $14 \mathrm{~g} /$ day. Daily recommendations for TDF and soluble fiber (SF) are 25 and $6 \mathrm{~g}$, respectively (USDA 2005).

Dietary Guidelines for Americans (USDA 2005) and current scientific evidence support greater consumption of whole grains and dietary fiber to reduce the risk for chronic disease. Evidence has shown that consumption of whole grains reduces risk of heart disease (Anderson and Hanna 2000; Hu et al 2000), certain types of cancer (Jacobs et al 1998; McCullough et al 2003; Montonen et al 2003), type-2 diabetes (Liu et al 2000; Montonen et al 2003), and all-cause mortality (Jacobs et al 2000; Jacobs et al 2001). Consumption of at least three $1-\mathrm{oz}$ equivalents of whole-grain products daily is recommended by the current dietary guidelines; at least half of daily grain intake should be from whole grains.

Barley is a grain that is receiving attention due to its $\beta$-glucan SF content. In May 2006, FDA finalized the rule that amended the regulation authorizing a health claim on the relationship between $\beta$-glucan soluble fiber from whole oat sources and reduced risk of coronary heart disease (CHD) by adding barley as an additional source of $\beta$-glucan soluble fiber eligible for the health claim (2ICFR101.81, FDA, and DHHS 2006). Of particular interest is the development of waxy, hulless barley cultivars that are consistently higher in $\beta$-glucan than the nonwaxy types (Yoon et al 1995).

$\beta$-Glucan intake from oats and barley has lowered plasma cholesterol and blood pressure, reduce postprandial serum glucose uptake and insulin resistance, and increase satiety (Heaton et al 1988; Anderson et al 1994; Brown et al 1999; Jenkins et al 2000 , 2002; Li et al 2003; Reyna et al 2003; Mohamed et al 2005).

\footnotetext{
'Human Nutrition \& Food Science Dept., California State Polytechnic University, Pomona, CA 91768 . Mention of a trade name, propriety product or specific equipment does not constitute a guarantee or warranty by Cal Poly Pomona University

${ }^{2}$ Corresponding author. Phone: 909-869-2180. Fax: 909-869-5078. E-mail address: mboteroomary@csupomona.edu

${ }^{3}$ ConAgra Foods Inc., Omaha, NE 68102.

${ }^{4}$ USDA/ARS/ERRC, Wyndmoor, PA 19038. Names are necessary to report factually on available data; however, the USDA nejther guarantees nor warrants the standard of the product, and the use of the name by the USDA implies no approval of the product to the exclusion of others that may also be suitable.

${ }_{5}$ University of Nebraska, Lincoln, NE 68588.

${ }^{6}$ USDA/ARS/WRRC. Albany, CA 94710.
}

doi: $10.1094 /$ CCHEM-86-4-0439

(c) 2009 AACC International, Inc
Whole-grain barley flour has potential for use as a health promoting ingredient. Replacement of a portion of wheat flour with whole barley flour in baked goods and grain-based applications can significantly increase the whole grain, total fiber, and soluble fiber content of the final product. The challenges are formulating products to achieve consumer acceptance of products that are whole-grain and fiber-enriched. Another challenge reported elsewhere is maintenance of $\beta$-glucan molecular weight during processing (baking), particularly yeast-leavened products. The use of cereal $\beta$-glucans as functional ingredients and applications for cereals and cereal components including $\beta$-glucans have been extensively reviewed by Brennan and Cleary (2005).

Incorporating whole grain barley flour containing $\beta$-glucan soluble fiber into tortillas is a reasonable approach to helping American consumers to meet dietary recommendations, especially for increasing whole grain and fiber intake for Hispanics, the largest and fastest growing minority in the United States.

Studies have shown that particle size of the wheat flour has an effect on baking potential and finished product attributes as measured on several baked goods including cookjes, cakes, noodles, bread, and tortillas (Kurimoto and Shelton 1988; Qarooni et al 1988; Yamamoto et al 1996; Wang and Flores 2000; Mao and Flores 2001; Zhang et al 2005). Furthermore, several researchers have reported on the effects of dietary fiber, barley $\beta$-glucan fractions, or barley flour on the quality of tortillas (Friend et al 1992; Ames et al 2006)

The objective of this study was to evaluate the effects of the particle size of whole barley flour on the quality and consumer acceptability of flour tortillas. To the authors' knowledge, no similar study has been published to-date.

\section{MATERIALS AND METHODS}

\section{Materials}

Prowashonupana whole barley flour (Sustagrain ConAgra Foods, Omaha, NE) with several particle size ranges including an average of $237 \pm 1.15 \mu \mathrm{m}$ for regular $(R), 131 \pm 0.90 \mu \mathrm{m}$ for intermediate (IM), and $68 \pm 1.85 \mu \mathrm{m}$ for microground (MG), along with a control bread flour $(\mathrm{C})$ that averaged $72 \pm 0.28 \mu \mathrm{m}$ were used in the study. Prowashonupana barley is an unusual hull-less and waxy barley cultivar with a shrunken endosperm and it has very low starch content $(30 \%)$, thick cell walls, high fiber $(30 \%$ min) of which $40 \%$ is $\beta$-glucan soluble fiber ( $12 \% \mathrm{~min})$. The other tortilla ingredients were purchased from a local grocery store (Diamond Bar, CA). 


\section{Flour Analyses}

Particle size distribution of all the individual flours used was determined on 35-g samples. Testing was conducted in triplicate using the American Society of Agricultural and Biological Engineers method S319.3 (ASAE 2003) with the micron air jet sieve (Version 2, Summit, NJ). Regular flour was analyzed using 50 , $100,150,212,250,300,355,425$, and 450 micron sieves; intermediate flour was analyzed using $50,75,100,125,150,180,212$, $250,300,355$, and 400 micron sieves; bread flour was analyzed using $20,38,50,63,75,90,100,125$, and 150 micron sieves; and microground flour was analyzed using $38,50,63,75,90,100$, 125,150 , and 175 micron sieves.

Fluorescence in cross-sectioned barley kernels, flours, and cut surfaces of cooked tortillas was examined using a model MZ FL3 stereofluorescence microscope equipped with a mercury 1 amp house, optics/filters for epifluorescence of UV-induced fluorescence and a DC200 charge couple device (color) camera (Leica Microsystems, Bannockburn, IL), similar to the techniques used to provide a rapid determination of ferulic acid as an indicator of wheat bran (Symons and Dexter 1991). For ease and economy of display, color digital images were converted to monochrome (gray) images, and intensity was inverted to easily visualize the dark (fluorescent) particles against a bright background. Microstructure of flour, dough and cooked tortilla samples was visualized with a model Quanta 200 FEG scanning electron microscope (SEM) (FEI, Hillsboro, OR) operated in the high-vacuum secondary electron imaging mode. Flours were applied directly to the surfaces of carbon adhesive tabs (Electron Microscopy Sciences, Hatboro, PA) mounted onto sample stubs. Loose, nonadherent particles were removed by exposing the surfaces of the samples to a jet of nitrogen gas at a delivery pressure at 80 psi. Remaining adherent particles on stub surfaces were coated with a thin layer of gold by DC sputtering and then examined by SEM. Samples of doughs and tortillas were excised with a stainless steel razor blade into $5 \mathrm{~mm} \times 20 \mathrm{~mm}$ blocks and immersed in $20 \mathrm{~mL}$ of fixative solution $(2.5 \%$ glutaraldehyde in $0.1 \mathrm{M}$ of imidazole buffer solution, $\mathrm{pH}$ 7.2) for two days. Samples were then washed in imidazole buffer and dehydrated in a graded series of ethanol solutions $(50,80$, and $100 \%)$. After dehydration, samples were frozen in liquid nitrogen and manually cross-fractured with the edge of a cold surgical scalpel blade. Fractured frozen fragments were thawed in absolute ethanol and critical-point-dried with liquid carbon dioxide. Dried samples were glued to specimen stubs with fracture faces oriented upward. Fractured faces were finally sputtered with a thin layer of gold for SEM.

Flour CIE-Lab color was measured in triplicate using a chroma meter (Minolta CR-410, Konica Minolta Sensing Americas, Ramsey, NJ) and lightness $\left(L^{*}\right)$, redness $\left(a^{*}\right)$, and yellowness $\left(b^{*}\right)$ values were recorded. A Minolta white calibration plate No. 17333240 for CR-200/CR-300/CR400 with $2^{\circ}$ OBSERVER was used. Calibration values were $Y=92.8, x=0.3134, y=$ 0.3193. The higher the $L^{*}$ value, the brighter the flour. Protein, ash, moisture, starch, and $\beta$-glucan content of flour samples were analyzed in triplicate by Approved Methods 46-30, 08-03, 44-15A or 44-19, 76-13, and 32-23, respectively (AACC International 2000).

Water absorption, peak time and mixing stability were measured in triplicate on bread flour and on blends of bread flour and whole grain barley flours at a 84:16 ratio using Approved Method 54-2I (AACC International 2000) and a farinograph (FA/R-2, C. W. Brabender Instruments, South Hackensack, NJ). The farinograph curve was centered at $500 \mathrm{BU}$.

\section{Tortilla Preparation}

The formula and procedure for tortilla making was based on the methods published by Mao and Flores (2001) and Bello et al (1991) with some modifications (Table I). All dry ingredients, including bread flour, Prowashonupana whole barley flour, baking powder (Clabber Girl, Terre Haute, IN), and salt (Morton iodized salt, Chicago, IL) were mixed in a Kitchen Aid mixer (K45SS, St. Joseph, MI) at speed 1 for $30 \mathrm{sec}$. Canola oil (Stater Brother's, Colton, CA) and water $\left(25 \pm 2{ }^{\circ} \mathrm{C}\right)$ were added and the doughs were mixed to full development for $2 \mathrm{~min}$ at speed 2 followed by $1 \mathrm{~min}$ at speed 4 . The dough was allowed to rest in a plastic covered mixing bowl at $25^{\circ} \mathrm{C}$ for $5 \mathrm{~min}$. Afterwards, the dough was portioned into $73-\mathrm{g}$ pieces and flattened for $10 \mathrm{sec}$ using a dough press (DP2000, Doughpro Proprocess, Paramount, CA) with a top plate temperature of $72.2^{\circ} \mathrm{C}$ and was then turned over and pressed for another $10 \mathrm{sec}$. Tortillas were cooked on a cast-iron pan at $232.2 \pm 2.8^{\circ} \mathrm{C}$ for $10 \mathrm{sec}$, turned over for $30 \mathrm{sec}$, and lastly turned over for $20 \mathrm{sec}$ giving each side a total of $30 \mathrm{sec}$ cooking time.

Cooked tortillas were allowed to cool to room temperature. The cooled tortillas were stored in double resealable plastic bags and held for $24 \mathrm{hr}$ at ambient temperature before testing and sensory evaluation. For sensory evaluation, a wedge of each tortilla was provided to panelists rather than whole tortillas to avoid satiety before the conclusion of the experiment.

Barley tortillas prepared for this experiment weighed $66 \mathrm{~g}$. However, nutrition composition data presented in Table II for the experimental tortillas and two commercial products are based on the Reference Amount Customarily Consumed (RACC) for tortillas of $55 \mathrm{~g}$ and information generated using software (Genesis R\&DSQL v.8.8, ESHA Research, Salem, OR). Per $55 \mathrm{~g}$, the experimental tortillas contained 148 calories, $7.9 \mathrm{~g}$ of whole grains, $5.2 \mathrm{~g}$ of protein, $2.8 \mathrm{~g}$ of total dietary fiber (TDF), and $1.5 \mathrm{~g}$ of $\beta$ glucan soluble fiber (SF), $3.3 \mathrm{~g}$ of total fat, $0.28 \mathrm{~g}$ of saturated fat, and $0 \mathrm{~g}$ of cholesterol.

The commercial tortillas tested were a low-fat, low-carb, highfiber tortilla (LF/LC/HF), and a handmade flour tortilla (HM). Per $55 \mathrm{~g}, \mathrm{LF} / \mathrm{LC} / \mathrm{HF}$ tortilla contained 157 calories, $5.9 \mathrm{~g}$ of whole wheat grain (not included on the label but supplied by manufacturer), $16 \mathrm{~g}$ of TDF, no SF, $4 \mathrm{~g}$ of total fat, $0 \mathrm{~g}$ of saturated fat and cholesterol. Tortilla label information on the HM product indicated that the tortillas were handmade and contained 179 calories, no whole grains, no TDF, no SF, $6 \mathrm{~g}$ of total fat, $1 \mathrm{~g}$ of saturated fat, and $0 \mathrm{~g}$ of cholesterol.

TABLE I

Formulas for Wheat Tortillas Enriched with Prowashonupana Whole Barley Flour

\begin{tabular}{lcccc}
\hline Ingredients & Control (\%) & $\begin{array}{c}\text { Regular, Intermediate, } \\
\text { \& Microground Whole } \\
\text { Barley Flour (\%) }\end{array}$ & $\begin{array}{c}\text { Control } \\
(\% \text { flour basis) }\end{array}$ & $\begin{array}{c}\text { Regular, Intermediate, } \\
\text { \& Microground Whole Barley } \\
\text { Flour }(\boldsymbol{\%} \text { flour basis) }\end{array}$ \\
\hline Prowashonupana whole barley flour & 0.0 & 9.2 & 0.0 & 15.9 \\
Bread flour & 60.9 & 48.7 & 100 & 84.1 \\
Baking powder & 1.0 & 1.0 & 1.6 & 1.7 \\
Iodized salt & 0.6 & 0.6 & 5.0 & 1.0 \\
Water $\left(25^{\circ} \mathrm{C}\right)$ & 33.5 & 36.7 & 6.6 & 63.4 \\
Canola oil & 4.0 & 3.8 & 164.2 & 6.6 \\
Total & 100 & 100.0 & 172.7 \\
\hline
\end{tabular}




\section{Tortilla Analyses}

Tortilla weight was determined on ten randomly selected tortillas. Diameter was determined as the average of two diagonal measurements of 10 randomly selected tortillas. Tortilla thickness was measured with a plastic dial caliper $(\mathrm{N}-143 \mathrm{~mm}$, General Hardware Manufacturing, New York, NY) as the average of three tortillas in three replicated trials.

Tortilla CIE-Lab color was measured on five randomly selected tortillas with a chroma meter (CR-410, Konica Minolta Sensing Americas, Ramsey, NJ). Lightness $\left(L^{*}\right)$, redness $\left(a^{*}\right)$, and yellowness $\left(b^{*}\right)$ values were recorded.

Water activity of the tortillas was determined on three randomly selected tortilla samples at $25^{\circ} \mathrm{C} \pm 0.2$ using a water activity meter (AquaLab 3TE, Decagon Devices, Pullman, WA).

Five randomly selected tortillas were mixed and tested in triplicate for protein, ash, moisture, starch, and $\beta$-glucan content using Approved Methods 46-30, 08-03, 44-15A or 44-19, 76-13, and 32-23, respectively (AACC International 2000).

Ten random samples of tortillas were selected for stretchability measurements with a texture analyzer (TA.XT plus, Texture Technologies, Scarsdale, NY/Stable Micro Systems, Godalming, Surrey, UK) equipped with a TA- 108 tortilla film fixture and a $1.90-\mathrm{cm}$ diameter rounded probe. The force-deformation curve for each tortilla provided data on maximum peak force, rupture distance, area under the curve of force (load) versus deformation, and gradient or modulus of elasticity. Settings included pretest speed of $6.0 \mathrm{~mm} / \mathrm{sec}$, test speed of $2.0 \mathrm{~mm} / \mathrm{sec}$, posttest speed of $10 \mathrm{~mm} / \mathrm{sec}$, distance of $30 \mathrm{~mm}$, and trigger force of $50 \mathrm{~g}$.

\section{Sensory Evaluation}

Ninety-five untrained panelists including students, faculty, and staff from Cal Poly Pomona University evaluated six randomly presented tortilla samples for overall acceptability (OA), appearance $(\mathrm{A})$, color $(\mathrm{CO})$, flavor $(\mathrm{F})$, and texture $(\mathrm{Tx})$ using a 9-point hedonic scale. Products tested included four experimental tortillas and two commercial brands of flour tortillas. The commercial products $(\mathrm{CP})$ included a handmade tortilla (HM) and a low-fat, low-carb, high-wheat fiber tortilla $(\mathrm{LF} / \mathrm{LC} / \mathrm{HF})$. Samples were served at room temperature $\left(25^{\circ} \mathrm{C}\right)$.

\section{Experimental Design and Statistical Analyses}

A total of 50 experimental tortillas were made for this experiment including bread flour (control) and three different blends of bread and whole barley flours (R, IM, and MG). The tortillas made were used for sensory (15), weight and dimensions (10), color and chemical analysis (5), water activity (3), texture (10), and images (5). Each barley flour had a different particle size distribution, while that of the bread flour remained constant. Data were collected under a completely randomized design. Unless otherwise noted, all tests were run in triplicate. Flour and tortilla data were analyzed using a generalized linear model in SAS (v.9.1, SAS Institute, Cary, NC). Least significant differences (LSD) were evaluated at the $95 \%$ confidence interval. Pearson correlation coefficients were calculated and significance established at the $99 \%$ confidence interval.

\section{RESULTS AND DISCUSSION}

\section{Flour Analyses}

Results from the particle size analysis (Table III) showed control (C), regular (R), intermediate (IM), and microground (MG) whole barley flours with average particle sizes of $72 \pm 0.28,237 \pm$ $1.15,131 \pm 0.9$, and $68 \pm 1.85 \mu \mathrm{m}$, respectively. Particle size distributions of all individual flours were significantly different from each other $(P<0.05)$. Average particle sizes for the corresponding blends were 97,81 , and $72 \mu \mathrm{m}$, respectively. These measurements are supported by the microscopic observations of UV-fluorescent particles in the flours. Figure 1 illustrates a cross-section of the

TABLE II

Nutrient Composition of Experimental ${ }^{\mathrm{a}}$ and Commercial $^{\mathrm{b}}$ Tortillas

\begin{tabular}{|c|c|c|c|c|c|c|c|c|}
\hline ESHA Analysis ${ }^{c}$ & $\mathbf{C}^{\mathrm{d}}$ & $\mathbf{R}^{\mathbf{d}}$ & $\mathbf{I M}^{\mathrm{d}}$ & $\mathbf{M G}^{\mathrm{d}}$ & $\mathbf{L F} / \mathbf{L C} / \mathbf{H F}^{\mathrm{d}}$ & $H_{M^{d}}$ & $L F / L C / H_{F}{ }^{d}$ & $H M^{d}$ \\
\hline Serving size (g) & 55 & 55 & 55 & 55 & 55 & 55 & 28 & 43 \\
\hline Calories & 155 & 148 & 148 & 148 & 157 & 179 & 80 & 140 \\
\hline Total carbohydrate (g) & 28 & 26 & 26 & 26 & 24 & 28 & 12 & 22 \\
\hline Total dietary fiber $(\mathrm{g})$ & 1.31 & 2.8 & 2.8 & 2.8 & 16 & 1 & 8 & $<1$ \\
\hline \multicolumn{9}{|l|}{ Soluble } \\
\hline Fiber $(\mathrm{g})$ & 0.13 & 1.6 & 1.5 & 1.5 & na & na & na & na \\
\hline Sugars $(\mathrm{g})$ & 0 & 0 & 0 & 0 & 0 & 0 & 0 & 0 \\
\hline Total fat (g) & 3.3 & 3.3 & 3.3 & 3.3 & 4 & 6 & 2 & 5 \\
\hline Saturated fat $(\mathrm{g})$ & $<1$ & $<1$ & $<1$ & $<1$ & 0 & 1 & 0 & 1 \\
\hline Trans fat $(\mathrm{g})$ & 0 & 0 & 0 & 0 & 0 & 0 & 0 & 0 \\
\hline Cholesterol (mg) & 0 & 0 & 0 & 0 & 0 & 0 & 0 & 0 \\
\hline Sodium (mg) & 228 & 216 & 216 & 217 & 471 & 205 & 240 & 160 \\
\hline Protein $(\mathrm{g})$ & 5.2 & 5.2 & 5.2 & 5.2 & 6 & 4 & 3 & 3 \\
\hline
\end{tabular}

${ }^{a} \mathrm{C}$, control, 0 whole barley flour (WBF); R, regular, 84:16 bread and regular WBF; IM, intermediate, 84:16 bread and intermediate WBF; MG, microground, 84:16 bread and microground WBF.

${ }^{\mathrm{b}} \mathrm{LF} / \mathrm{LC} / \mathrm{HF}$, low-fat, low-carb, high-fiber; HM, handmade.

${ }^{c}$ Based on Reference Amount Customarily Consumed (RACC) of $55 \mathrm{~g}$ for tortillas. Per serving size noted on the label.

${ }^{d}$ Genesis R\&DSQL (v.8.8, ESHA Research, Salem, OR).

TABLE III

Characteristics of Experimental Flour ${ }^{\mathrm{a}}$

\begin{tabular}{|c|c|c|c|c|c|c|c|c|c|}
\hline \multirow[b]{2}{*}{ Type of Flour } & \multirow{2}{*}{$\begin{array}{l}\text { Avg Particle Size } \\
(\mu \mathrm{m})\end{array}$} & \multirow{2}{*}{$\begin{array}{l}\text { Protein } \\
(\% d b)\end{array}$} & \multirow{2}{*}{$\begin{array}{c}\text { Ash } \\
(\% \mathrm{db})\end{array}$} & \multirow{2}{*}{$\begin{array}{c}\text { Moisture } \\
(\%)\end{array}$} & \multirow{2}{*}{$\begin{array}{c}\text { Starch Content } \\
\text { (\% db) }\end{array}$} & \multirow{2}{*}{$\begin{array}{c}\beta \text {-Glucan } \\
\text { (\% db) }\end{array}$} & \multicolumn{3}{|c|}{ Color } \\
\hline & & & & & & & $L^{*}$ & $a^{*}$ & $b^{*}$ \\
\hline Control (bread) & $72.1 \mathrm{a}$ & $17.07 \mathrm{a}$ & $0.69 \mathrm{a}$ & $11.91 \mathrm{a}$ & $70.10 \mathrm{a}$ & $0.28 \mathrm{a}$ & $93.72 \mathrm{a}$ & $-0.21 \mathrm{c}$ & $8.88 \mathrm{c}$ \\
\hline Regular (WBF) & $237.6 \mathrm{~b}$ & $21.57 \mathrm{~b}$ & $1.90 \mathrm{~b}$ & $8.98 b$ & $22.07 \mathrm{~b}$ & $16.00 \mathrm{~b}$ & $86.86 \mathrm{c}$ & $0.45 \mathrm{a}$ & $15.09 \mathrm{a}$ \\
\hline Intermediate (WBF) & $130.9 \mathrm{c}$ & $20.01 \mathrm{c}$ & $2.12 \mathrm{c}$ & $7.24 \mathrm{c}$ & $24.25 c$ & $15.87 b$ & $88.32 \mathrm{bc}$ & $0.32 \mathrm{~b}$ & 14.27ab \\
\hline Microground (WBF) & $68.4 \mathrm{~d}$ & $18.43 \mathrm{~d}$ & $2.32 \mathrm{~d}$ & $5.32 \mathrm{~d}$ & $25.55 \mathrm{~d}$ & $15.83 \mathrm{~b}$ & $89.43 b$ & $0.31 \mathrm{~b}$ & $13.41 \mathrm{~b}$ \\
\hline
\end{tabular}

a Values followed by different letters are significantly different $(P<0.05), n=3$. WBF, whole barley flour. 
Prowashonupana whole barley kernel. The bright fluorescent band corresponded to the location of the aleurone. Under comparable imaging conditions, the flours showed widely distributed, submil-

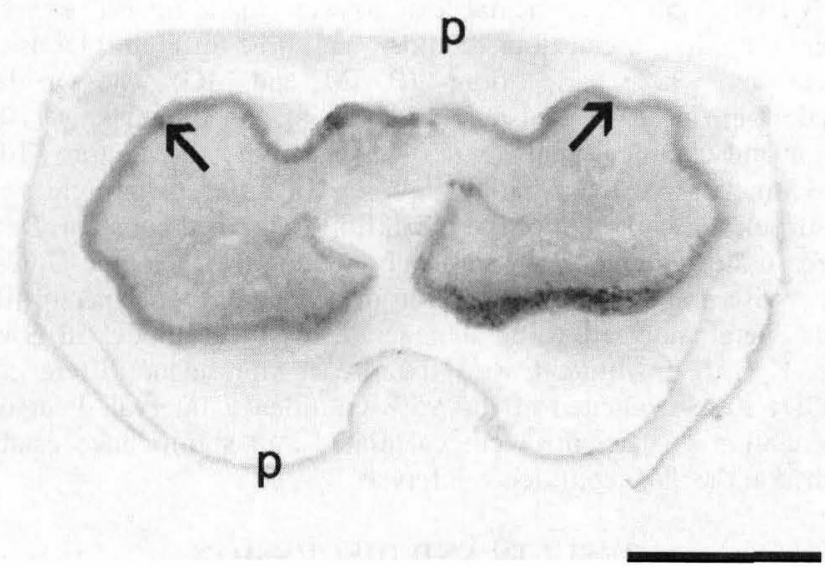

Fig. 1. Epifluorescence of Prowashonupana barley kernel cross-section. Outline of aleurone is dark (arrows); inside profile of palea and lemma of the pericarp (p). Scale bar $=1 \mathrm{~mm}$. limeter sized fluorescent particles, comparable to the fluorescent intensity of the aleurone that roughly paralleled the measured sizes described above (Fig. 2A-D). C contained the most uniform, small fluorescent particles. $\mathrm{R}$ contained more large particles, and IM contained a mixture of large and small particles. MG fluorescent particles were the smallest but less uniform. Symons and Dexter (1991) reported a decrease in percent fluorescence noted as percent aleurone with a decrease in wheat flour particle size.

The microstructure of the flours revealed many regular, roughly spherical submillimeter size particles with some distinctive topographical features in the R, IM, and MG flours that are probably related to components of the barley, tightly integrated with agglomerated starch granules (Fig. 3A-D). Hatcher et al (2005) generated SEM micrographs for two hull-less barley flours (one waxy and the other high amylose) and identified the starch, protein, cell wall fragments, and bran particle components. Specks in barley-supplemented noodles were attributed to fragments of testa, endosperm cell walls, and aleurone of barley. Such tissues, as noted by the authors, are mainly made up of $\beta$-glucan, arabinoxylans, and other nonstarch polysaccharides.

Color. Color analyses of barley and bread flours (Table III) showed lower $L^{*}$ for all WBF compared with the control or bread flour (93.72). The smaller particle size of MG flour contributed to a higher $L^{*}$, and lower $a^{*}$ and $b^{*}$ values as compared to $\mathrm{R}$ flour, which had a larger particle size.

Chemical Analyses. As particle size decreased among barley flours, protein content, and moisture content decreased, while ash
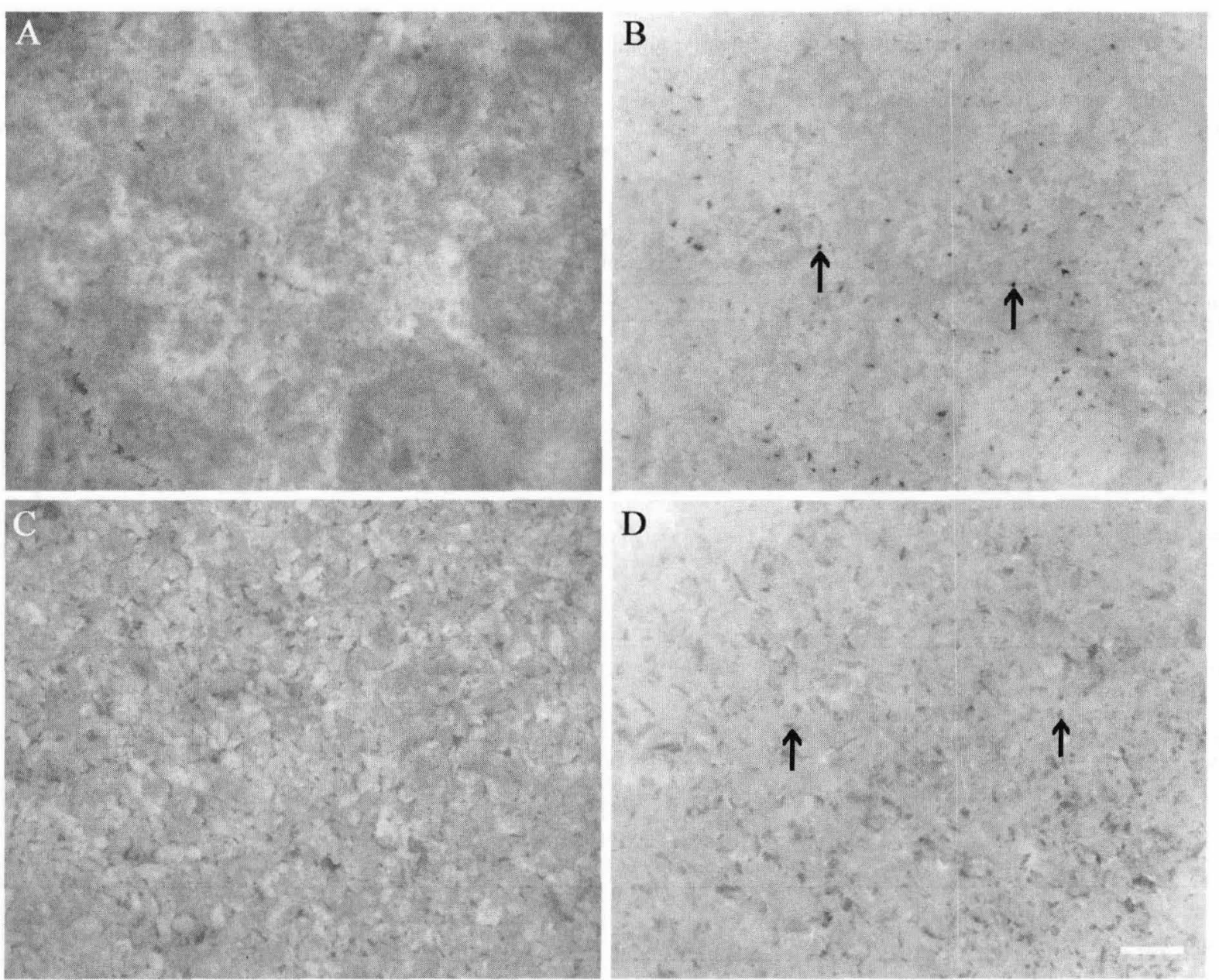

Fig. 2. Epifluorescence of flours. Reflected white light and UV-induced fluorescence in identical areas of the bulk flour samples, representing particles at and slightly below the surface. A, superficial structure of Control or bread flour; $\mathbf{B}$, distribution of regular and small fluorescent particles (arrows); $\mathbf{C}$, coarse superficial structure of Regular whole barley flour (WBF); D, distribution of larger fluorescent particles (arrows). Scale bar $=1 \mathrm{~mm}\left(\approx 7 \mathrm{~mm}{ }^{2}\right.$ areas). (continued on page 443) 
and starch content increased (Table III). The protein content of C flour was less than in barley flours. Regular, IM, and MG flours contained $21.6,20$, and $18.4 \%$ protein, respectively. These values are very high compared with hulled and other hull-less waxy barleys published elsewhere (12.2 and $15.1 \%$, respectively) (Bhatty 1999). Moisture content decreased as WBF particle size decreased at 5.3-9\%. The greater attrition and possible heat generated during milling of smaller particle sized flours explains the increase in moisture loss. Symons and Dexter (1991) reported a moisture reduction among reground samples of No. 1 Canada western red spring wheat. In contrast, ash content for the same barley flours, increased as particle size decreased (1.9-2.3\%). Similar to ash, starch content increased as particle size decreased (22.1-25.6\%), which is due to the release of cleaner starch granules from the protein matrix during grinding. Such release was facilitated by the lack of strength of the protein matrix. Similar findings have also been reported by Wang and Flores (2000), when grinding hard red winter, hard white winter, and soft red winter wheat flours. Prowashonupana barley has significantly lower starch content than other waxy hull-less barley flours. The $\mathrm{R}$ and MG flours were ground using different mills (hammer and impact, respectively). The IM flour was made from a 50:50 blend of $\mathrm{R}$ and $\mathrm{MG}$ flours. The differences in mills used for $\mathrm{R}$ and $\mathrm{MG}$ flours may have contributed to the differences in composition.

$\beta$-Glucan results were $0.28,16,15.9$, and $15.8 \%$ for $\mathrm{C}, \mathrm{R}, \mathrm{IM}$, and MG flours, respectively. No differences in $\beta$-glucan content were found among barley flours. In this study, milling appears not to have affected $\beta$-glucan content of the different flours but expo- sure to high heat when tortillas were cooked seems to have weakened the $\beta$-glucan structure and partially depolimerized the $\beta$ glucan molecular chain.

Quinde at el (2004) reported $\beta$-glucan content for whole and abraded grains of different genotypes of barley. The hull-less waxy barley genotype, CDC Candle, had the highest $\beta$-glucan content among the genotypes tested (10\%). The next highest $\beta$-glucan content $(9.8 \%)$ was in the hull-less waxy barley genotype SH97110.

Farinograph testing. Differences were found among treatments with respect to water absorption, farinograph peak time, and mixing stability (Table IV). Water absorption was the lowest for $\mathrm{C}$ flour $(61.5 \%)$ and increased as particle size decreased with values at $72.6,74.6$, and $76 \%$ for flour blends containing $\mathrm{R}$, IM, and MG flours, respectively. Wang and Flores (2000) reported a similar increase in water absorption for hard red winter and hard white winter wheat flour fractions with a reduction in particle size. The increased water absorption for barley flours as compared with that of the $\mathrm{C}$ is also due to the presence of soluble fiber in the barley flours, which increased water demands. Mohammed et al (2005) reported a similar behavior when incorporating an oat bran hydrocolloid containing the $\beta$-glucan soluble fiber in hard red winter wheat noodles. Farinograph peak time was also the shortest for $\mathrm{C}$ flour $(6.3 \mathrm{~min})$, while peak time values for barley flour blends decreased with a decrease in particle size from $8.5 \mathrm{~min}$, $7.8 \mathrm{~min}$, and $7 \mathrm{~min}$ for R, IM, MG flours, respectively. The decrease in peak time may be related to the lower protein content reported as particle size decreased among barley flours. Mixing


Fig. 2. (continued from page 442) Epifluorescence of flours. Reflected white light and UV-induced fluorescence in identical areas of the bulk flour samples, representing particles at and slightly below the surface. E, surface of Intermediate WBF; F, areas of large and small fluorescent particles (arrows); G, surface of Microground WBF; $\mathbf{H}$, mostly small fluorescent particles (arrows). Scale bar $=1 \mathrm{~mm}\left(\approx 7 \mathrm{~mm}^{2}\right.$ areas). 
stability was the longest for the $\mathrm{C}$ flour $(12.8 \mathrm{~min})$, followed by $\mathrm{R}$ (8.5 min), IM (7 min), and MG (5.8 min) barley flour blends. Thus, a decrease in WBF particle size caused a decrease in mixing stability. The mixing stability of $\mathrm{C}$ was higher than barley flour blends due to the stronger, more concentrated network of functional gluten in bread flour compared with the whole barley flour and bread flour blends. Although protein content for barley flours was higher than that of the control ( $100 \%$ bread flour), the gluten or structural protein content is lower. According to Wichser et al (1947), lower protein content coupled with small particle sizes impedes the protein from forming an adequate matrix during dough development. Mohammed et al (2005) also reported a decrease in dough stability with the presence of $\beta$-glucan containing flours.

Tortilla analyses. As noted above, the compact internal microstructure of doughs and tortillas in frozen-fractured preparations also revealed evidence of barley aleurone and micrometer-scale fragments of cell wall, tightly integrated with large and small starch granules and complex intergranular matrix (Fig. 4A-H). Images of all dough treatments showed starch granules embedded in the protein matrix. Different size cell wall fragments were observed based on the different particle sizes of WBF. No appreciable amounts of cell wall fragments were found in the $\mathrm{C}$ dough (Fig. 4A), while the cell wall matrix could be seen clearly in the $\mathrm{R}$ dough (Fig. 4C). A combination of large and small elongated cell wall fragments were found in the IM dough (Fig. 4E) and finer cell wall fragments were observed in the MG dough (Fig. 4G) due to the smaller particle size of the corresponding barley flour. Additionally, all doughs had partially exposed, smooth-surfaced starch granules embedded in a continuous matrix, composed either of a mixture of small granules and irregular networks of fine filaments or small granules embedded in sheets of solid material.
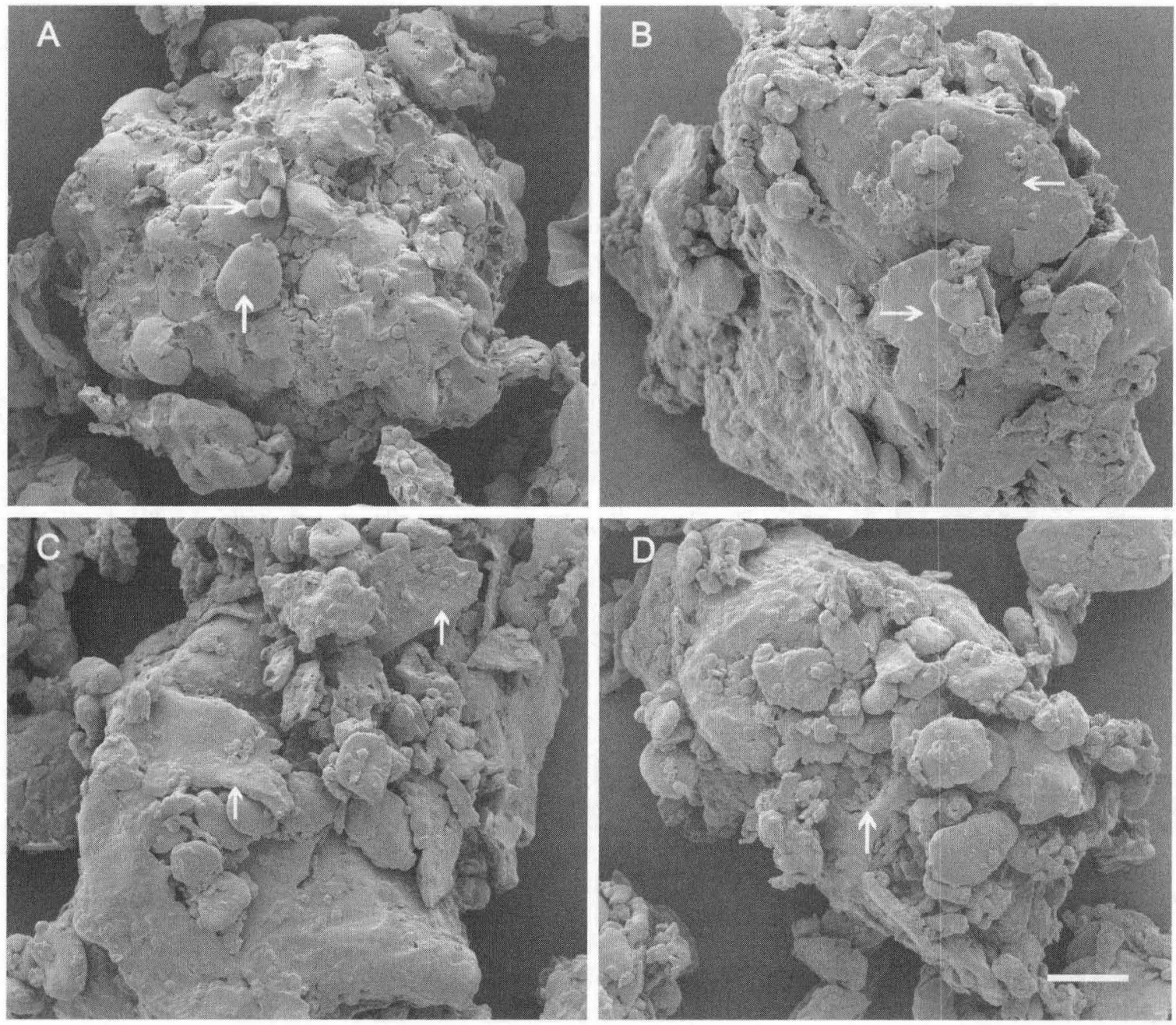

Fig. 3. Topographical SEM images of particles in the flours. A, Control or bread flour with agglomerated large and small starch granules (arrows); B. Regular whole barley flour (WBF) with agglomerated large and small starch granules similar to Control, including several irregular, flat-surfaced fragments indicated by arrows; C, Intermediate WBF with agglomerated starch granules and flat-surfaced pieces (arrows); D, Microground WBF with starch granules agglomerated with flat-surfaced components (arrow). Scale bar $=10 \mu \mathrm{m}$.

TABLE IV

Farinograph Characteristics of Flour Blends ${ }^{a}$

\begin{tabular}{|c|c|c|c|}
\hline Flour Treatments & Water Absorption (\%) & Peak Time (min) & Mixing Stability (min) \\
\hline Control (bread) & $61.53 \mathrm{a}$ & $6.33 \mathrm{a}$ & $12.83 \mathrm{a}$ \\
\hline Blend 84:16 (bread:regular) & $72.60 \mathrm{~b}$ & $8.50 \mathrm{~b}$ & $8.50 \mathrm{~b}$ \\
\hline Blend 84:16 (bread:intermediate) & $74.56 \mathrm{c}$ & $7.83 c$ & $7.00 \mathrm{c}$ \\
\hline Blend 84:16 (bread:microground) & $76.00 \mathrm{~d}$ & $7.00 \mathrm{~d}$ & $5.83 \mathrm{~d}$ \\
\hline
\end{tabular}

a Values followed by different letters are significantly different within columns $(P<0.05) ; n=3$. 
Various surface contours and fractured profiles of cell wall fragments were consistently found in all areas of dough samples. Large fragments of aleurone with intact cell wall profiles and enclosed cells were found in R dough (Fig. 4C), and mixtures of large and small fragments of cell wall profiles were observed in IM dough (Fig. 4E). Smaller profiles of cell wall fragments were often found in MG dough (Fig. 4G).

The topography of microstructure prepared from cooked tortillas was different from the doughs. In cooked tortillas, fractures went along the same fracture plane as the fractured continuous matrix, rather than around the periphery of the starch granules (Fig. 4B, D, F, H), suggesting a uniform and cohesive mixture of components in the cooked tortillas. Protein matrices and starch granules in all experimental tortillas were more compact and uniform than in the corresponding doughs. The presence of cell wall fragments in barley tortillas made the starch-protein layers less compact. Even though the particle size of $\mathrm{C}$ flour was larger than $\mathrm{MG}$ flour, the starch and protein layer for the $\mathrm{C}$ tortilla was the most compacted because of the insignificant amount of cell wall fragment found in C flour tortilla (Fig. 4B). In contrast, Mohamed et al (2005) reported a more compact image of noodles including Nutrim, an oat bran extract containing soluble fiber, with less space in between starch granules relative to the control. Starch and protein layers of $\mathrm{R}$ tortillas (Fig. 4D) were not as packed as in the other barley treatments because of the larger particle size of the corresponding barley flour. Structural differences among doughs and tortillas are due to changes occurring during dough pressing and heating. When the dough is heated, the gas cells expand, starch gelatinizes, protein cross links, fat melts into the surface area of air cells, gas cells rupture and, on occasion, cell walls can be fragmented (Autio and Laurikainen 1997). Seetharaman et al (1997) studied the effect of soluble and insoluble fibers on the microstructure of wheat flour tortillas and found they played divergent roles. When $8 \%$ soluble fiber was used, doughs had poor gluten development and significant starch gelatinization during baking, resulting in tortillas that were dense and had a pasty crumb. In contrast, doughs containing $8 \%$ insoluble fiber had better gluten development. However, inclusion of $8 \%$ insoluble fiber disrupted the gluten network, which made the air bubbles collapse, resulting in the appearance of starch granules enveloped in a thin and continuous film of protein.

Stereofluorescence. Stereofluorescence images of the internal, cut surfaces of tortillas (Fig. 5A-H) revealed a widely scattered distribution of blue-fluorescent, submillimeter-size particles located at the surface and, less distinctly, within the tortilla matrix, comparable to particles in the flours (Fig. 2A-D); the largest fluorescent particles were found in the $\mathrm{R}$ and $\mathrm{IM}$ flours; $\mathrm{C}$ contained small asymmetric particles. MG contained the smallest and isodiametric particles. Blue autofluorescence reveals the presence of ferulic acid, which is localized mostly in the aleurone cell walls
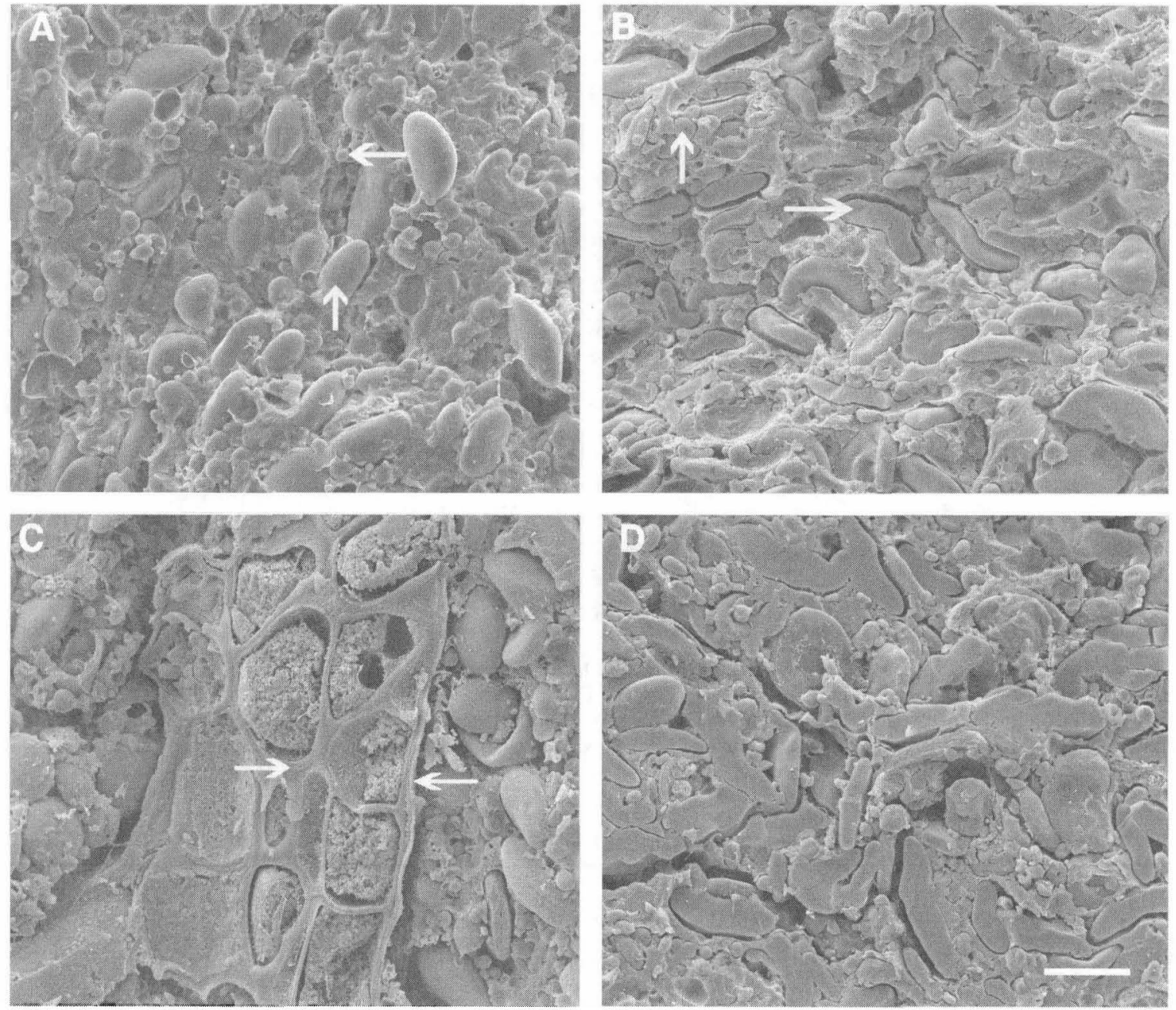

Fig. 4. Topographical SEM images of fracture faces in doughs and tortillas. A, Control or bread flour dough with intact large and small starch granules (arrows) embedded in a mixed amorphous and particulate matrix; B, Control or bread flour tortilla containing both fractured and intact, large and small starch granules (arrows) embedded in the matrix; C, Regular whole barley flour (WBF) dough with intact starch granules together with a fragment of barley aleurone (arrows); D, Regular WBF tortilla with numerous fractured large starch granules and intact small granules in an amorphous-particulate matrix. Scale bar $=10 \mu \mathrm{m}$. (contiuned on page 446) 
of the grain kernels and is therefore present in the dough and tortillas.

Weight and dimensions. The characteristics of tortillas made from different particle size barley flours are shown in Table V.

Color. Color data of all WBF tortillas showed no differences in $L^{*}(61)$ but were darker than C (69), LC/LF/HF (66), and HM tortillas (78) (Table V). The HM tortilla was the lightest of all tortillas tested. The $\mathrm{C}$ tortilla and the other $\mathrm{CP}$ showed no differences in $L^{*}$. The LC/LF/HF tortillas were redder than the other tortillas tested. No differences in $a^{*}$ were found among IM and MG tortillas, while values for $\mathrm{R}$ tortillas were lower than the other two barley tortillas. The decrease in particle size may have af- fected the visibility of the tannins present in the WBF in IM and MG tortillas. Yellowness values $\left(b^{*}\right)$ of the $\mathrm{LF} / \mathrm{LC} / \mathrm{HF}$ and IM tortillas were the highest (19), while that of the HM tortilla was the lowest (15.1). Values for C, R, and MG tortillas were the same (17.5) and, like $a^{*}$, that of the IM and MG showed no differences.

Water activity. Water activity of all WBF tortillas showed no differences $(0.981)$ (Table $\mathrm{V}$ ). Both $\mathrm{CP}$ had the lowest water activity of all tortillas tested (0.953) and displayed no differences.

Chemical analyses. On a dry basis, C, R, and IM tortillas had the same protein content $(15.1 \%)$ and IM, MG tortillas also had the same value $(14.4 \%$ ) (Table VI). These findings are similar to those reported above on flour analyses, where WBF particle size
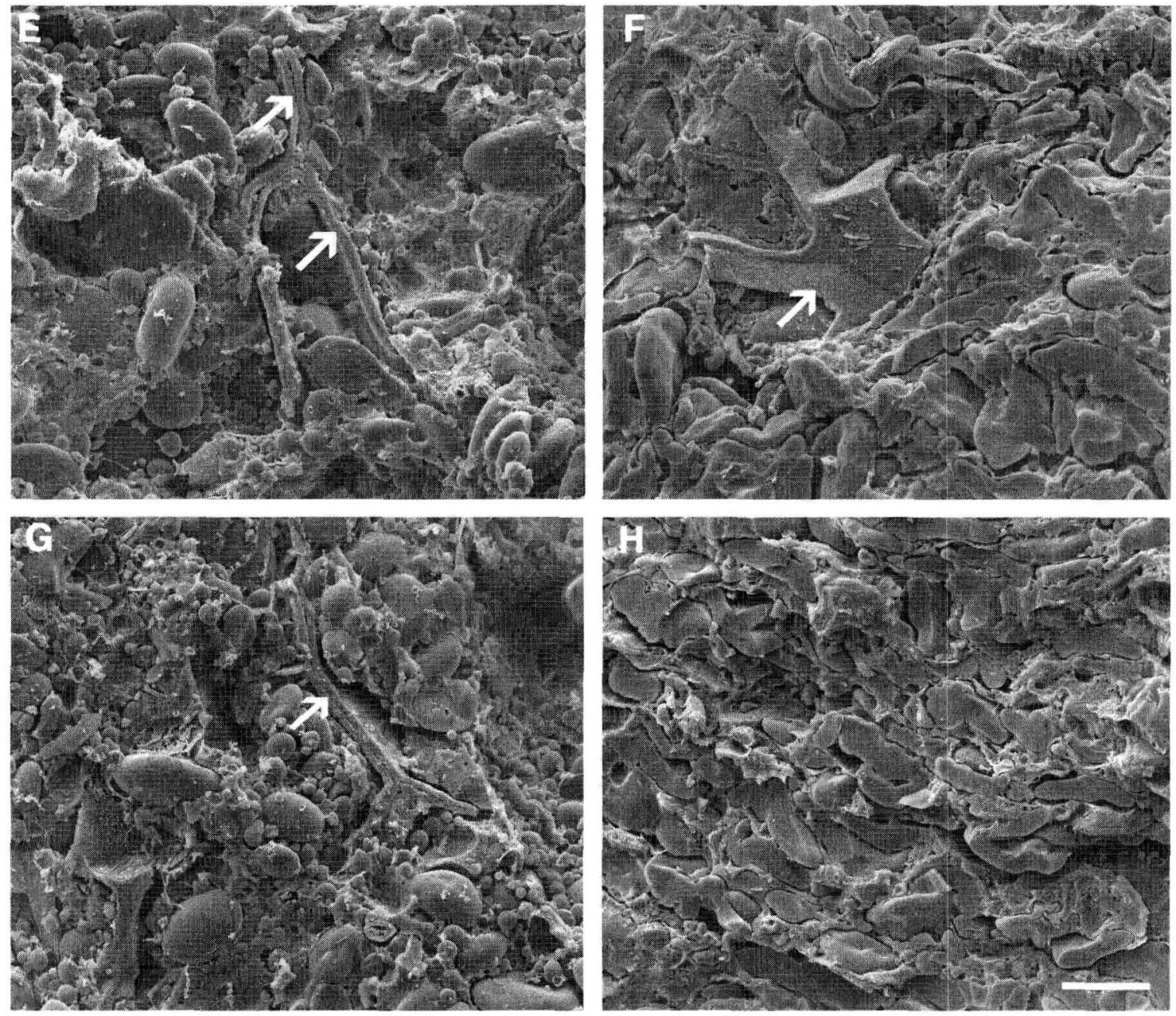

Fig. 4. (continued from page 445) Topographical SEM images of fracture faces in doughs and tortillas. E, Intermediate WBF dough illustrating intact large and small granules and large fragments resembling cell wall (arrows); F, Intermediate WBF tortilla with fractured large starch granules, intact small granules and a cell wall fragment (arrow); G, Microground WBF dough with intact starch granules and cell wall fragment (arrow); H, Microground WBF tortilla with numerous fractured large starch granules and a few intact small granules separated by a complex matrix. Scale bar $=10 \mu \mathrm{m}$.

TABLE V

Characteristics of Experimental Tortillas and Commercial Products ${ }^{\mathbf{a}}$

\begin{tabular}{|c|c|c|c|c|c|c|c|}
\hline \multirow[b]{2}{*}{ Tortilla Type } & \multirow[b]{2}{*}{ Weight (g) } & \multirow[b]{2}{*}{ Diameter $(\mathbf{c m})$} & \multirow[b]{2}{*}{ Thickness (cm) } & \multicolumn{3}{|c|}{ Color } & \multirow[b]{2}{*}{$a_{w}$} \\
\hline & & & & $L^{*}$ & $a^{*}$ & $b^{*}$ & \\
\hline Control (bread) & $65.8 \mathrm{a}$ & $18.2 \mathrm{~b}$ & $0.39 \mathrm{a}$ & $68.48 \mathrm{~b}$ & $-1.00 \mathrm{~d}$ & $17.09 \mathrm{c}$ & $0.972 b$ \\
\hline Regular ( $84: 16$ bread and regular WBF) & $65.5 \mathrm{a}$ & $17.9 \mathrm{bc}$ & $0.29 \mathrm{ab}$ & $61.02 \mathrm{c}$ & $0.75 \mathrm{c}$ & $17.35 \mathrm{c}$ & $0.981 \mathrm{a}$ \\
\hline Intermediate ( $84: 16$ bread and intermediate WBF) & $65.8 \mathrm{a}$ & $17.4 c$ & $0.34 a b$ & $60.76 c$ & $1.68 \mathrm{~b}$ & $18.52 \mathrm{ab}$ & $0.978 \mathrm{ab}$ \\
\hline Microground $84: 16$ bread and microground WBF) & $65.9 \mathrm{a}$ & $17.7 \mathrm{bc}$ & $0.28 \mathrm{ab}$ & $59.52 \mathrm{c}$ & $1.771 \mathrm{~b}$ & $17.54 \mathrm{bc}$ & $0.977 \mathrm{ab}$ \\
\hline Handmade $(\mathrm{CP})$ & $49.5 \mathrm{~b}$ & $21.2 \mathrm{a}$ & $0.33 \mathrm{ab}$ & $78.47 \mathrm{a}$ & $-1.84 \mathrm{e}$ & $15.06 \mathrm{~d}$ & $0.950 \mathrm{c}$ \\
\hline Low-fat, low-carb, high-fiber (CP) & $30.6 \mathrm{c}$ & $15.9 \mathrm{~d}$ & $0.23 \mathrm{~b}$ & $66.17 \mathrm{~b}$ & $4.01 \mathrm{a}$ & $19.03 \mathrm{a}$ & $0.953 \mathrm{c}$ \\
\hline
\end{tabular}

a Values followed by different letters are significantly different $(P<0.05) ; n=10$ for weight and diameter; $n=5$ for $L, a, b ; n=3$ for thickness and $a_{\mathrm{w}}$; WBF, whole barley flour; $\mathrm{CP}$, commercial product. 
decreased as protein content decreased. In contrast, ashmontent was highest in MG tortillas $(2.5 \%)$ and lowest in $\mathrm{C}$ tortillas $(2.2 \%)$. These results are also consistent with those reported on the flour analyses. No differences in moisture content were found among all barley tortillas. Moisture content of $\mathrm{C}$ tortillas was the lowest $(33.6 \%)$ and different from that of all barley tortillas $(36.3 \%)$. The increased water demand during dough preparation for WBF tortillas explains their higher moisture content. Starch content of $\mathrm{C}$ tortillas was the highest $(70.4 \%)$, followed by IM $(62 \%)$, microground $(61 \%)$, and regular $(60.2 \%)$. These results coincide for the starch content of $\mathrm{C}$ flour but contrast with those of experimental flours because starch content in WBF increased as particle size decreased. $\beta$-Glucan was the lowest for the control tortilla $(0.24 \%)$, which correspond to the absence of barley flour. Among WBF tortillas, the highest value was for $\mathrm{R}$ tortillas $(2.8 \%)$ and the lowest for IM and MG tortillas $(2.7 \%)$. The decrease in $\beta$ glucan content with a decrease in particle size may be due to a weakening of the $\beta$-glucan structure during milling and partial depolymerization of the $\beta$-glucan molecular chain during exposure to high heat when tortillas were cooked (Klamczynski et al 2004; Symons and Brennan 2004).

Stretchability of tortillas. Table VII shows the textural properties for the experimental tortillas and two commercial products. Stretchability of a flour tortilla was expressed as the maximum force and rupture distance measured with a texture analyzer. The $\mathrm{C}$ and $\mathrm{R}$ tortillas showed the highest peak force and had no differ-
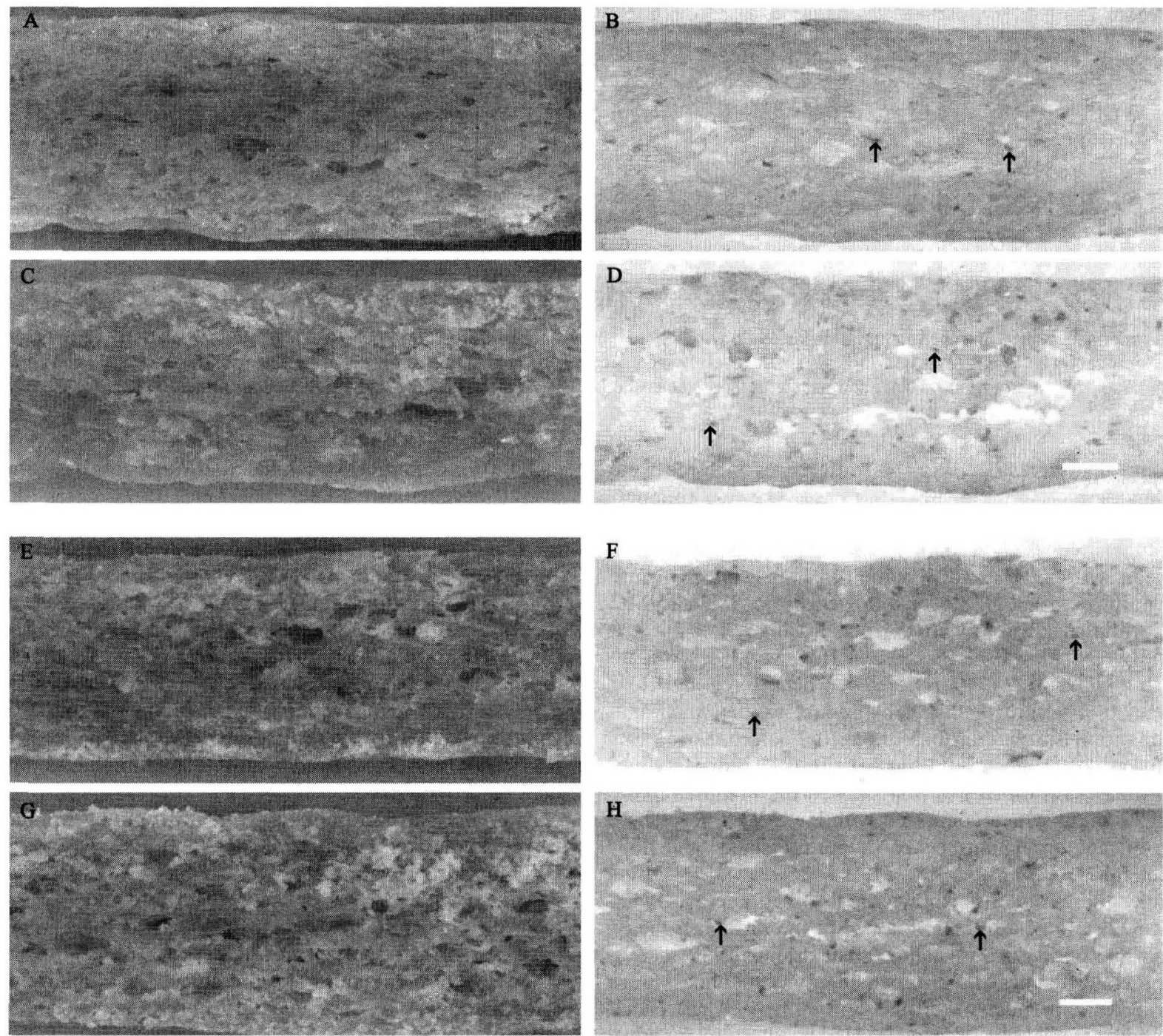

Fig. 5. Epifluorescence of tortillas. Reflected white light and UV-induced fluorescence in identical areas of the tortillas. A, Cut surface of Control or bread flour tortilla illustrating the matrix and air spaces (dark areas); B, uniformly small fluorescent particles (arrows) in Control tortilla; $\mathbf{C}$, cut surface of Regular whole barley flour (WBF) tortilla; D, dispersion of large and small fluorescent particles (arrows); E, cut surface of Intermediate WBF tortilla; $\mathbf{F}$, large and small fluorescent particles (arrows); G, cut surface of Microground WBF tortilla; $\mathbf{H}$, corresponding area with fluorescent particles (arrows). Scale bar $=1 \mathrm{~mm}$

TABLE VI

Chemical Analyses of Experimental Tortillas ${ }^{\mathrm{a}}$

\begin{tabular}{|c|c|c|c|c|c|}
\hline Tortilla Type & Protein $(\% \mathrm{db})$ & $\operatorname{Ash}(\%$ db) & Moisture (\%) & Starch Content ( $\%$ db) & $\beta$-Glucan ( $\%$ db) \\
\hline Control & $15.28 \mathrm{a}$ & $2.16 \mathrm{a}$ & $33.55 \mathrm{a}$ & $70.41 \mathrm{a}$ & $0.24 \mathrm{a}$ \\
\hline Regular ( $84: 16$ bread and regular WBF) & $15.44 \mathrm{a}$ & $2.36 \mathrm{~b}$ & $36.06 \mathrm{~b}$ & $60.22 \mathrm{~d}$ & $2.83 \mathrm{~b}$ \\
\hline Intermediate ( $84: 16$ bread and intermediate WBF) & $15.05 \mathrm{ab}$ & $2.38 \mathrm{~b}$ & $36.29 \mathrm{~b}$ & $61.99 \mathrm{~b}$ & $2.69 \mathrm{c}$ \\
\hline Microground $84: 16$ bread and microground WBF) & $14.36 \mathrm{~b}$ & $2.45 \mathrm{c}$ & $35.86 \mathrm{~b}$ & $61.03 \mathrm{c}$ & $2.68 \mathrm{c}$ \\
\hline
\end{tabular}

\footnotetext{
a Values followed by different letters are significantly different $(P<0.05)$; WBF, whole barley flour.
} 
TABLE VII

Stretchability of Experimental Tortillas and Commercial Products ${ }^{\mathrm{a}}$

\begin{tabular}{|c|c|c|c|c|}
\hline Type of Tortilla & Max Force (kg) & Rupture Distance (mm) & Area $(\mathrm{kg} \cdot \mathbf{m m})$ & Gradient $(\mathrm{kg} / \mathrm{mm})$ \\
\hline Control & $0.90 \mathrm{a}$ & $11.00 \mathrm{~b}$ & $4.72 a$ & $0.09 \mathrm{a}$ \\
\hline Regular ( $84: 16$ bread and regular WBF) & $0.84 \mathrm{ab}$ & $11.33 \mathrm{~b}$ & $4.68 \mathrm{a}$ & $0.08 \mathrm{ab}$ \\
\hline Intermediate ( $84: 16$ bread and intermediate WBF) & $0.75 \mathrm{~b}$ & $10.25 \mathrm{bc}$ & $3.78 \mathrm{a}$ & $0.08 \mathrm{~b}$ \\
\hline Microground $84: 16$ bread and microground WBF) & $0.74 \mathrm{~b}$ & $10.11 \mathrm{bc}$ & $3.80 \mathrm{a}$ & $0.08 \mathrm{~b}$ \\
\hline Handmade (CP) & $0.41 \mathrm{c}$ & $9.50 \mathrm{c}$ & $2.01 \mathrm{~b}$ & $0.04 \mathrm{c}$ \\
\hline Low fat, low carb, high fiber (CP) & $0.42 \mathrm{c}$ & $15.67 \mathrm{a}$ & $4.15 \mathrm{a}$ & $0.03 \mathrm{c}$ \\
\hline
\end{tabular}

a Values followed by different letters are significantly different $(P<0.05) ; n=10$; WBF, whole barley flour; CP, commercial product.

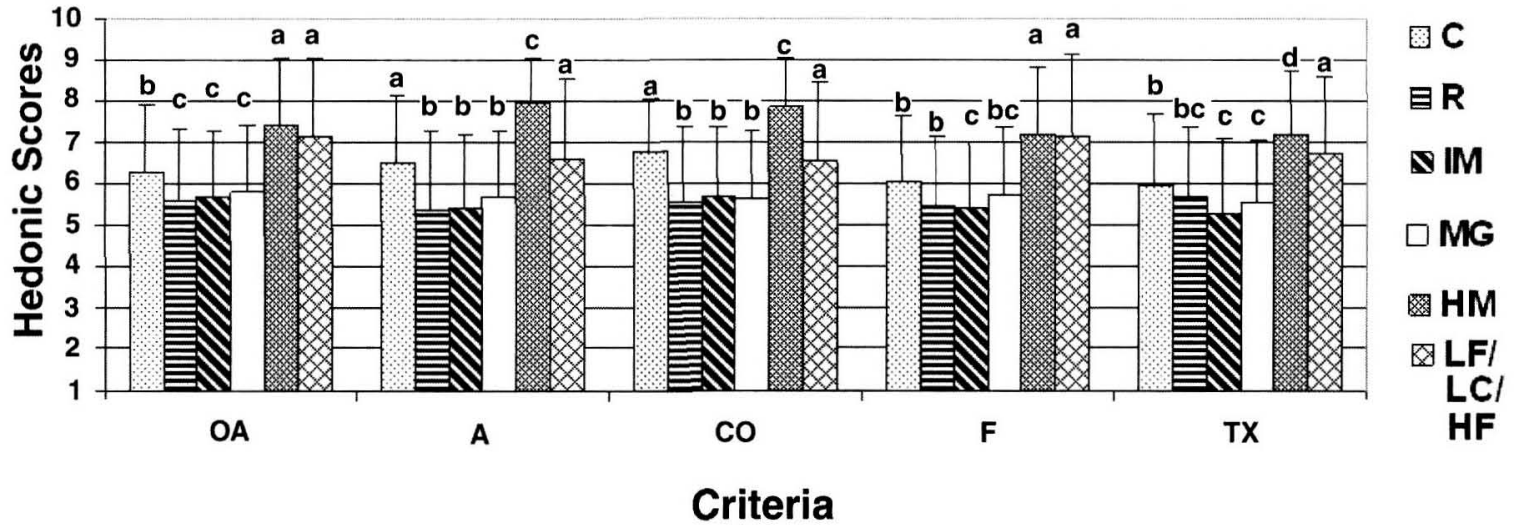

Fig. 6. Consumer acceptance of experimental tortillas made with whole barley flour of different particle size and commercial tortillas. Bars with different letters are significantly different $(P<0.05 ; n=95)$. OA, overall acceptability; A, appearance; $\mathrm{CO}$, color; F, flavor; TX, texture; C, control; R, regular; IM, intermediate; MG, microground; HM, handmade commercial tortilla; LF/LC/HF, low-fat, low-carb, high-fiber commercial tortilla.

ences among themselves $(0.9 \mathrm{~kg})$. No differences in force were observed among the barley tortillas $(0.84 \mathrm{~kg})$. The two commercial products had the lowest peak force $(0.41 \mathrm{~kg})$ and thus were the least stretchable. Protein content (dry basis) was highest for tortillas made with $\mathrm{C}, \mathrm{R}$, and IM flours $(15.1 \%)$, while moisture content was lowest for C $(33.6 \%)$ followed by $\mathrm{R}$, IM, and MG $(35.9 \%)$. Tortilla peak forces were correlated with $a_{w}(r=0.69, P$ $<0.01)$ and weight $(r=0.71, P<0.01)$. However, there was no significant relationship $(P>0.01)$ between peak force and flour protein content. Rupture distance, expressed as the maximum distance the probe traveled through the tortilla before tearing was the same for all experimental tortillas $(11 \mathrm{~mm})$. The low-fat, lowcarb, high-fiber (LF/LC/ HF) tortilla showed the highest rupture distance $(15.7 \mathrm{~mm})$, which contrasted with low peak force. There was no significant correlation between rupture distance and flour protein content $(P>0.01)$.

Area under the curve, also known as absorbed energy (Wang and Flores 1999), indicates the toughness of the tortilla. It measures the tortilla's ability to withstand a great strain without tearing or breaking. No differences in absorbed energy or toughness were found among all experimental tortillas $(3.8 \mathrm{~kg} . \mathrm{mm})$. The LF/LC/ HF tortilla had a similar area to experimental tortillas $(4.2 \mathrm{~kg} . \mathrm{mm})$, but the handmade tortilla (HM) had the lowest area $(2 \mathrm{~kg} . \mathrm{mm})$, thus it was the least tough of all tortillas tested. Gradient or Young's modulus is calculated as the slope of the initial straightline portion of the force in kilograms and the rupture distance in millimeters. It measures elasticity: the tortilla's ability to return to its original form after the applied force is removed (Wang and Flores 1999), thus the lower the gradient, the more elastic the product. Both $\mathrm{C}$ and $\mathrm{R}$ tortillas showed the same gradient $(0.09$ $\mathrm{kg} / \mathrm{mm})$, as well as all WBF tortillas $(0.08 \mathrm{~kg} / \mathrm{mm})$. Both CP were the most elastic of all tortillas tested $(0.03 \mathrm{~kg} . \mathrm{mm})$. Gradients were correlated with $a_{\mathrm{w}}(r=0.79, P<0.01)$ and tortilla weight $(r$ $=0.83, P<0.01$ ).

Sensory evaluation. Figure 6 shows the consumer acceptance of WBF tortillas with flours of different particle size and commer- cial tortillas. Participants rated the WBF tortillas similarly for overall acceptability (5.8), appearance (5.7), color (5.7), flavor (5.8), and texture (5.7), but rated $\mathrm{C}$ higher than the barley tortillas for overall acceptability (6.3), appearance (6.5), and color (6.8). No differences in flavor were reported among $C, R$, and MG (6.1), and in texture among $C$ and $R$ tortillas (6). Participants found no differences in appearance and color between $C$ and $\mathrm{LC} / \mathrm{LF} / \mathrm{HF}$ tortilla. Also, the two $\mathrm{CP}$ were rated higher than WBF tortillas for all criteria tested. No differences were detected among panelists for CP in overall acceptability (7.4) and flavor (7.2), while higher scores were given to HM for appearance ( 7.9 vs. $6.6)$, color (7.9 vs. 6.5$)$ and texture (7.2 vs. 6.7) as compared with the LC/LF/HF tortilla.

Although not nutritionally identical to the experimental tortillas, the commercial tortillas included in the study were the closest available in the market. They either had a low content of fat or contained whole grains or were made by hand like the tortillas made in our study. They were included for benchmarking purposes, which is important in product development efforts to provide direction on consumer preference and quality for future steps. Per $55 \mathrm{~g}$, the experimental tortillas contained 148 calories, $7.9 \mathrm{~g}$ of whole grains, $2.8 \mathrm{~g}$ of total dietary fiber (TDF), $1.5 \mathrm{~g}$ of $\beta$-glucan soluble fiber, $3.3 \mathrm{~g}$ of total fat, $0.28 \mathrm{~g}$ of saturated fat and $0 \mathrm{~g}$ of cholesterol; while $\mathrm{CP}$ (LF/LC/HF and HM) contained more calories (157 and $179 \mathrm{cal}$, respectively); a nondisclosed amount of whole wheat grain and no whole grain, respectively; 16 and $0 \mathrm{~g}$ of TDF, respectively; no soluble fiber and cholesterol in both cases; more fat ( 4 and $6 \mathrm{~g}$ of total fat, respectively); and 0 and $\mathrm{I} g$ of saturated fat, respectively.

\section{Correlation Coefficients Among Flour and Tortilla \\ Parameters}

Tables VIII and IX show correlation coefficients among flour and tortilla parameters and the effects of those parameters on the tortilla properties. Relationships among two parameters represented in bold values are significant at $P<0.01$. 
TABLE VIII

Pearson Correlation Coefficients $(r)$ Among Tortilla and Flour Parameters ${ }^{a, b}$

\begin{tabular}{|c|c|c|c|c|c|c|c|c|c|c|c|c|c|c|c|c|c|}
\hline \multirow[b]{2}{*}{ Parameter } & \multicolumn{17}{|c|}{ Tortilla Parameter } \\
\hline & SF & SD & SA & SG & $a_{w}$ & TL* & Ta* & $\mathbf{T b}^{*}$ & WT & Ta & TM & TS & TB & $\mathbf{A}$ & $\mathbf{C}$ & $\mathbf{F}$ & $\mathbf{T X}$ \\
\hline SA & 0.76 & 0.61 & & & & & & & & & & & & & & & \\
\hline SG & 0.96 & & 0.57 & & & & & & & & & & & & & & \\
\hline$a_{\mathrm{w}}$ & 0.69 & & & 0.79 & & & & & & & & & & & & & \\
\hline TL* & & & & & -0.80 & & & & & & & & & & & & \\
\hline $\mathrm{Ta}^{*}$ & & 0.59 & & & & -0.60 & & & & & & & & & & & \\
\hline $\mathrm{Tb}^{*}$ & & 0.54 & & & & -0.60 & 0.80 & & & & & & & & & & \\
\hline WT & 0.71 & -0.60 & & 0.83 & 0.85 & & & & & & & & & & & & \\
\hline WD & & -0.60 & -0.40 & & & 0.64 & -0.80 & -0.80 & & & & & & & & & \\
\hline TPR & & & & & & & -0.80 & & & & & & & & & & \\
\hline $\mathrm{Ta}$ & & & & & & & 0.91 & & & & & & & & & & \\
\hline $\mathrm{TM}$ & & & & & 0.71 & & 0.77 & & & 0.87 & & & & & & & \\
\hline TS & & & & & -0.70 & & -0.70 & & & -0.90 & -0.90 & & & & & & \\
\hline TB & & & & & 0.72 & & 0.80 & & & 0.93 & 0.98 & -0.98 & & & & & \\
\hline C & & & & & & & & & & & & & & 0.71 & & & \\
\hline $\mathrm{F}$ & & & & -0.40 & & & & -0.40 & -0.40 & & & & & 0.48 & 0.46 & & \\
\hline TX & -0.40 & & -0.30 & -0.40 & & & & -0.40 & & & & & & 0.47 & 0.51 & 0.64 & \\
\hline $\mathrm{OA}$ & -0.40 & & -0.40 & -0.40 & & & & -0.40 & -0.40 & & & & & 0.55 & 0.59 & 0.70 & 0.70 \\
\hline fPR & & & & & 0.78 & & & & & 0.71 & 0.90 & -0.90 & 0.91 & & & & \\
\hline fa & & & & & & & 0.91 & & & 0.98 & 0.93 & -0.90 & 0.96 & & & & \\
\hline $\mathrm{fM}$ & & & & & & 0.72 & -0.90 & & & -1.00 & -0.80 & 0.79 & -0.82 & & & & \\
\hline fS & & & & & -0.70 & & -0.80 & & & -0.90 & -1.00 & 0.98 & -1.00 & & & & \\
\hline $\mathrm{fL}^{*}$ & & & & & -0.80 & & & & & -0.80 & -0.90 & 0.90 & -0.92 & & & & \\
\hline $\mathrm{fa}^{*}$ & & & & & 0.71 & & & & & 0.85 & 0.94 & -1.00 & 0.97 & & & & \\
\hline $\mathrm{fb}^{*}$ & & & & & 0.76 & & 0.71 & & & 0.84 & 0.94 & -0.90 & 0.97 & & & & \\
\hline $\mathrm{fB}$ & & & & & & & 0.82 & & & 0.94 & 0.98 & -0.98 & & & & & \\
\hline \multicolumn{18}{|l|}{ Ps } \\
\hline WA & & & & & & & 0.91 & & & 0.98 & 0.94 & -0.90 & 0.96 & & & & \\
\hline PT & & & & & & & & & & & 0.79 & -0.80 & 0.78 & & & & \\
\hline MS & & & & & & & -0.90 & & & -1.00 & -0.90 & 0.86 & -0.91 & & & & \\
\hline
\end{tabular}

a Relationships among two parameters represented in bold values are significant at $P<0.01$

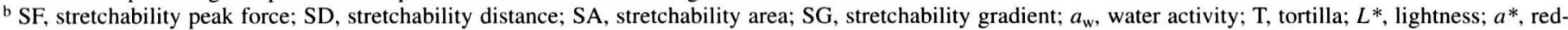

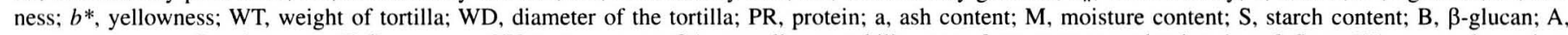

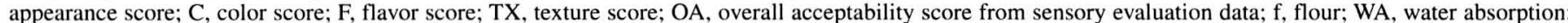

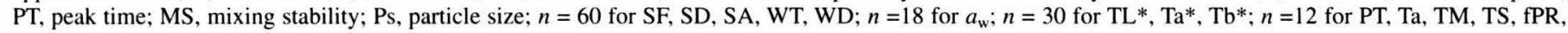
$\mathrm{fa}, \mathrm{fM}, \mathrm{fS}, \mathrm{fL}^{*}, \mathrm{fa}^{*}, \mathrm{fb}^{*}, \mathrm{fB}, \mathrm{Ps}, \mathrm{WA}, \mathrm{PT}, \mathrm{TB}, \mathrm{MS} ; n=551$ for A; $n=546$ for $\mathrm{C}$ and $\mathrm{F} ; n=544$ for TX; $n=540$ for OA.

Tortilla appearance had a positive correlation with tortilla color $(0.71)$ and overall acceptability $(0.55)$.

Tortilla color was positively correlated with texture $(0.51)$ and overall acceptability score (0.59). Tortilla flavor was positively correlated with texture score $(0.64)$ and overall acceptability score (0.7). Tortilla texture had a positive correlation with overall acceptability (0.7). Characteristics of good quality of the flour tortillas are soft, opaque, no cracks present when folded, flexible, and light in color and well puffed (Wang and Flores 1999; Waniska 1999; Pascut et al 2004).

\section{CONCLUSIONS}

The effect of different particle size whole barley flour on the quality of wheat tortillas was evaluated. It showed that tortillas made with the largest particle size of whole barley flour (R) were the most similar in protein content, texture, and flavor compared to the control (C) tortillas made with refined bread flour. Reduction in whole barley flour (WBF) particle size did not alter the sensory scores as measured by overall acceptability, appearance, color, flavor, and texture. UV-induced fluorescence of flours, doughs, and tortillas confirmed particle size differences in each WBF treatment. Whole barley flour tortillas were darker than the control, and the two commercial products (CP). A decrease in WBF particle size showed a decreasing trend in $\beta$-glucan content of tortillas. Larger peak forces and gradients were observed between WBF tortillas and CP indicating the higher stretchability and lower elasticity of the former. No flavor differences were reported among control, regular, or microground tortillas but higher scores were given to both CP in all attributes tested.
The development of tortillas containing WBF is feasible and it is an approach that can be taken to help consumers meet dietary recommendations for increasing whole grain and fiber intake. A further increase in quality and consumer appeal could be obtained from reformulating the products to more closely match commercial products already existing in the market place, while providing significant amounts of whole grains, such as the handmade tortilla which had the highest score for appearance, color, and texture. For this work, tortillas made with WBF were formulated to contain close to $8 \mathrm{~g}$ of whole grains and over $0.75 \mathrm{~g}$ of $\beta$-glucan soluble fiber $/ 55 \mathrm{~g}$ serving.

The tortillas could be reformulated to meet the FDA approved health claim relating soluble fiber from oats, barley or psyllium and a reduced risk of heart disease (21 CFR 101.81, FDA and DHHS 2006).

Marketing challenges for these functional tortillas remain. A potential approach is to increase consumer awareness of the health benefits of tortillas made with whole barley flour in conjunction with their introduction into the marketplace.

\section{ACKNOWLEDGMENTS}

We would like to thank Jhanel Wilson and Guoping Bao (USDA ERRC, Wyndmoor, PA) for conducting particle size analyses and for assistance with microstructure and fluorescence images, respectively; to Maggie Chiu (USDA - WRRC, Albany, CA) for assistance with $\beta$-glucan testing of flours and tortillas; to Marc Johnson and Jim Fabry (Texture Technologies, Scarsdale, NJ) for technical assistance; and to Broc Sandelin ( $\mathrm{Cal}$ Poly Pomona, Pomona, CA) for statistical assistance with correlations. Appreciation is also extended to the California Agricultural Research Initiative (ARI) for funds provided to partially support this project. 
TABLE IX

Pearson Correlation Coefficients ( $r$ ) Among Flour and Tortilla Parameters ${ }^{\mathrm{a}, \mathrm{b}}$

\begin{tabular}{|c|c|c|c|c|c|c|c|c|c|c|}
\hline \multirow{2}{*}{$\begin{array}{l}\text { Tortilla } \\
\text { Parameter }\end{array}$} & \multicolumn{10}{|c|}{ Flour Parameter } \\
\hline & fPR & fa & $\mathbf{f M}$ & fS & fL* & fa* & $\mathrm{fb}^{*}$ & $\mathbf{f B}$ & Ps & WA \\
\hline \\
\hline \multicolumn{11}{|l|}{ SG } \\
\hline \\
\hline TL* & & & & & & & & & & \\
\hline \multicolumn{11}{|l|}{$\mathrm{Ta}^{*}$} \\
\hline \multicolumn{11}{|l|}{$\mathrm{Tb}^{*}$} \\
\hline \multicolumn{11}{|l|}{ WT } \\
\hline \multicolumn{11}{|l|}{ WD } \\
\hline \multicolumn{11}{|l|}{ TPR } \\
\hline \multicolumn{11}{|l|}{$\mathrm{Ta}$} \\
\hline \multicolumn{11}{|l|}{ TM } \\
\hline \multicolumn{11}{|l|}{ TS } \\
\hline \multicolumn{11}{|l|}{ TB } \\
\hline \multicolumn{11}{|l|}{$\mathrm{C}$} \\
\hline \multicolumn{11}{|l|}{$\mathrm{F}$} \\
\hline \multicolumn{11}{|l|}{$\mathrm{TX}$} \\
\hline \multicolumn{11}{|l|}{$\mathrm{OA}$} \\
\hline \multicolumn{11}{|l|}{ fPR } \\
\hline $\mathrm{fa}$ & 0.76 & & & & & & & & & \\
\hline $\mathrm{fM}$ & & -0.94 & & & & & & & & \\
\hline fS & -0.91 & -0.96 & & & & & & & & \\
\hline $\mathrm{fL}^{*}$ & -0.96 & -0.81 & & 0.93 & & & & & & \\
\hline fa* & 0.94 & 0.88 & & -0.97 & -0.93 & & & & & \\
\hline $\mathrm{fb}^{*}$ & 0.96 & 0.88 & & -0.97 & -0.99 & 0.96 & & & & \\
\hline $\mathrm{fB}$ & 0.89 & 0.97 & -0.84 & -1.00 & -0.91 & 0.96 & 0.96 & & & \\
\hline Ps & 0.81 & & & & -0.73 & & & & & \\
\hline WA & 0.77 & 0.99 & -0.94 & -0.96 & -0.82 & 0.89 & 0.89 & 0.97 & & \\
\hline PT & 0.94 & & & -0.79 & -0.90 & 0.84 & 0.87 & 0.75 & 0.90 & \\
\hline MS & & -0.98 & 0.97 & 0.90 & 0.74 & -0.81 & -0.81 & -0.92 & & -0.98 \\
\hline
\end{tabular}

a Relationships among two parameters represented in bold values are significant at $P<0.01$

${ }^{\mathrm{b}} \mathrm{SF}$, stretchability peak force; SD, stretchability distance; SA, stretchability area; SG, stretchability gradient; $a_{\mathrm{w}}$, water activity; T, tortilla; $L^{*}$, lightness; $a^{*}$, redness; $b^{*}$, yellowness; WT, weight of tortilla; WD, diameter of the tortilla; PR, protein; a, ash content; M, moisture content; S, starch content; B, $\beta$-glucan; A, appearance score; C, color score; F, flavor score; TX, texture score; OA, overall acceptability score from sensory evaluation data; f, flour; WA, water absorption; PT, peak time; MS, mixing stability; Ps, particle size; $n=60$ for SF, SD, SA, WT, WD; $n=18$ for $a_{\mathrm{w}} ; n=30$ for TL*, Ta*, Tb*; $n=12$ for PT, Ta, TM, TS, fPR, fa, fM, fS, $\mathrm{fL}^{*}, \mathrm{fa}^{*}, \mathrm{fb}^{*}, \mathrm{fB}, \mathrm{Ps}, \mathrm{WA}, \mathrm{PT}, \mathrm{TB}, \mathrm{MS} ; n=551$ for $\mathrm{A} ; n=546$ for $\mathrm{C}$ and $\mathrm{F} ; n=544$ for TX; $n=540$ for OA.

\section{LITERATURE CITED}

AACC International. 2000. Approved Method of American Association of Cereal Chemist, 10th Ed. Methods 46-30, 08-03, 44-19, 76-13, and 3223. The Association: St Paul, MN.

Ames, N., Rhymer, C., Rossnagel, B., Therrien, M., Ryland, D., Dua, S., and Ross, K. 2006. Utilization of diverse hull-less barley properties to maximize food product quality. Cereal Foods World 51:23-28.

Anderson, J. W., and Hanna. T. J. 2000. Whole grains and protection against coronary heart disease: What are the active components and mechanisms? Am. J. Clin. Nutr. 71:307-308.

Anderson, J. W., Smith, B. M., and Gustafson, N. J. 1994. Health benefits and practical aspects of high-fiber diets. Am. J. Clin. Nutr. 59:1242S$1247 \mathrm{~S}$.

Arndt, E. A. 2006. Whole-grain barley for today's health and wellness needs. Cereal Foods World 5I:20-22.

ASAE Standards. 2003. ASAE S319.3 - Method of determining and expressing fineness of feed materials by sieving. Pages 589-592 in ASAE Standards 2003, 50th Ed. ASAE: St. Joseph, MI.

Autio, K., and Laurikainen, T. 1997. Relationships between flour/dough microstructure and dough handling and baking properties. Trends Food Sci. Technol. 8:181-185.

Bello, A. B., Serna-Saldivar, S. O., Waniska, R. D., and Rooney, L. W. 1991. Methods to prepare and evaluate wheat tortillas. Cereal Foods World 36:315-321

Bhatty, R. S. 1999. The potential of hull-less barley. Review. Cereal Chem. 76:589-599.

Brennan, C. S., and Cleary, L. J. 2005. The potential use of cereals $(1 \rightarrow 3$, $1 \rightarrow 4)-\beta$-D-glucans as functional food ingredients. Review. J. Cereal Sci. 42:1-13.

Brown, L., Rosner, B., Willett, W. W., and Sacks, F. M. 1999. Cholesterollowering effects of dietary fiber: a meta-analysis. Am. Soc. Clin. Nutr. 69:30-42.

Friend, C. P., Serna-Saldivar, S. O., Waniska, R. D., and Rooney, L. W.
1992. Increasing the fiber content of wheat tortillas. Cereal Foods World 37:325-328.

Hatcher, D. W., Lagasse, S., Dexter, J. E., Rossnagel, B., and Izydorczyk, M. 2005. Quality characteristics of yellow alkaline noodles enriched with hull-less barley flour. Cereal Chem. 82:60-69.

Heaton, K. W., Marcus, S. N., Emmett, P. M., and Bolton, C. H. 1988. Particle size of wheat, maize, and oat test meals: Effects on plasma glucose and insulin responses and on the rate of starch digestion in vitro. Am. J. Clin. Nutr. 47:675-682.

Hu, F. B., Rimm, E. B., Stampfer, M. J., Aschrio, A., Spiegelman, D., and Willet, W. C. 2000. Prospective study of major dietary pattern and risk of coronary heart disease in men. Am. J. Clin. Nutr. 72:912-921.

Jacobs, D. R., Marquart, L., Slavin, J., and Kushi, L. H. 1998. Wholegrain intake and cancer: An expanded review and meta-analysis. Nutr. Cancer 30:85-96.

Jacobs, D. R., Pereira, M. A., Meyer, K. A., and Kushi, L. H. 2000. Fiber from whole grains, but not refined grains is inversely associated with all-cause mortality in older women: The Iowa Women's Health Study. J. Am. Coll. Nutr. 19:326S-330S.

Jacobs, D. R., Meyer H. E., and Solvoll, K. 2001. Reduced mortality among whole grain bread eaters in men and women in the Norwegian county study. Eur. J. Clin. Nutr. 55:137-143.

Jenkins, D. J. A., Kendall, C. W. C., Axelsen, M., Augustin, L. S. A., and Vuksan, V. 2000. Viscous and non-viscous fibres, non-absorbable and low glycaemic index carbohydrates, blood lipids and coronary heart disease. Curr. Opinion Lipid. 11:49-56.

Jenkins, D. J., Kendall, C. W. C., Vuksan, V., Vidgen, E., Parker, T., Faulkner, D., Mehling, C. C., Garsetti, M., Testolin, G., Cunnane, S. C., Ryan, M., and Corey, P. N. 2002. Soluble fiber intake at a dose approved by the U.S. Food and Drug Administration for a claim of health benefits: Serum lipid risk factors for cardiovascular disease assessed in a randomized controlled crossover trial. Am. J. Clin. Nutr. 75:834-839.

Klamczynski, A. P., Knuckles, B. E., and Glenn, G. M. 2004. Puffing and 
jet cooking affect solubility and molecular weight of barley $\beta$-glucans. J. Food Process. Preserv. 28:433-441.

Kurimoto, Y., and Shelton, D. R. 1988. The effect of flour particle size on baking quality and other flour attributes. Cereal Foods World 33:429433.

Li, J., Kaneko, T., Qin, L.-Q., Wang, J., Wang, Y., and Sato, A. 2003. Long-term effects of high dietary fiber intake on glucose tolerance and lipid metabolism in GK rats: Comparison among barley, rice, and cornstarch. Metabolism. 52:1206-1210.

Liu, S., Manson, J. E., Stampfer, M. J., Hu, F. B., Giovannucci, E., Colditz, G. A., Hennekens, C. H., and Willell, W. C. 2000. A prospective study of whole-grain intake and risk of type 2 diabetes mellitus in U.S. women. Am. J. Clin. Nutr. 90:1409-1415.

McCullough, M. L., Robertson, A. S., Chao, A., Jacobs, E. J., Stampfer, M. J., Jacobs, D. R., Diver, W. R., Calle, E. E., and Thun, M. J. 2003. A prospective study of whole grains, fruits, vegetables and colon cancer risk. Cancer Causes Control 14:959-970.

Mao, Y., and Flores, R. A. 2001. Mechanical starch damage effects on wheat flour tortilla texture. Cereal Chem. 78:286-293.

Mohamed, A. A., Rayas-Duarte, P., Xu, J., Palmquist, D. E., and Inglett, G. E. 2005. Hard red winter wheat/Nutrim OB alkaline fresh noodles: Processing and texture analysis. J. Food Sci. 70:S1-S7.

Montonen, J., Knekt, P., Järvinen, R., Aromaa, A., and Reunanen, A. 2003. Whole-grain and fiber intake and the incidence of type 2 diabetes. Am. J. Clin. Nutr. 77:622-629.

Pascut, S., Kelekci, N., and Waniska, R. D. 2004. Effect of wheat protein fraction on flour tortilla quality. Cereal Chem. 81:38-43.

Qarooni, J., Moss, H. J., Orth, R. A., and Wooton, M. 1988. The effect of flour properties on the quality of Arabic bread. J. Cereal Sci. 7:95-107.

Quinde, Z., Ulrich, S. E., and Baik B.-K. 2004. Genotypic variation in color and discoloration potential of barley-based food products. Cereal Chem. 81:752-758.

Reyna, N. Y., Cano, C., Bermudez, V. J., Medina, M. T., Souki, A. J., Ambard, M., Nunez, M., Ferrer, M. A., and Inglett, G. E. 2003. Sweeteners and beta-glucans improve metabolic and anthropometrics variables in well controlled type 2 diabetic patients. Am. J. Therapeutics 10:438-443.

Seetharaman, K., McDonough, C. M., Waniska, R. D., and Rooney, L. W. 1997. Microstructure of wheat flour tortillas: effect of soluble and insoluble fibres. Food Sci. Technol. Int. 3:181-188.
Symons, L. J., and Brennan, C. S. 2004. The influence of $(1 \rightarrow 3)(1 \rightarrow 4)-\beta$ D-glucan-rich fractions from barley on the physicochemical properties and in-vitro reducing sugar release of white wheat breads. J. Food Sci. 69:C463-C467.

Symons, S. J., and Dexter, J. E. 1991. Computer analysis of fluorescence for the measurement of flour refinement as determined by flour ash content, flour grade color, and tristimulus color measurements. Cereal Chem. 68:454-460.

USDA. 2005. Dietary Guidelines for Americans. National Agriculture Library. Published online at www.health.gov/dietaryguidelines/ dga2005/ document/pdf/executivesummary.pdf. USDA: Washington. DC.

USDA. 2006. FDA and DHHS. Food labeling. Health claims: Soluble dietary fiber from certain foods and coronary heart disease. 21 CFR 101.81. Code of Federal Regulations. Published online at www. gpoaccess.gov/cfr/index.html. USDA: Washington, DC.

Wang, L., and Flores, R. A. 1999. Effect of different wheat class and their flour milling streams on textural properties of flour tortillas. Cereal Chem. 76:496-502.

Wang, L., and Flores, R. A. 2000. Effect of flour particle size on the textural properties of flour tortillas. J. Cereal Sci. 31:263-372.

Waniska, R. D. 1999. Perspective on flour tortillas. Cereal Foods World 44:471-473.

Williams, C. L., Hyman, L. L., Daniels, S. R., Robinson, T. N., Steinberger, J., Paridon, S., and Bazzare, T. 2002. Cardiovascular health in Childhood: A statement for health professionals from the committee on atherosclerosis hypertension and obesity in the young (AHOPY) of the council on cardiovascular in the young. Am. Heart Assoc. Circulation 106:143-160.

Wischer, F. W., Shellenberger, J. A., and Pence, R. O. 1947. Relationship of the physical properties of wheat flour to granulation. Cereal Chem. $24: 381-393$

Yamamoto, H., Worthington, S. T., Hou, G., and Ng, P. K. W. 1996. Rheological properties and baking qualities of selected soft wheats grown in the United States. Cereal Chem. 73:215-221.

Yoon, S. H., Berglund, P. T., and Fastnaught, C. E. 1995. Evaluation of selected barley cultivars and their fractions for $\beta$-glucan enrichment and viscosity. Cereal Chem. 72:187-190.

Zhang. Y., Quail, K., Mugford, D. C., and He, Z. 2005. Milling quality and white salt noodle color of Chinese winter wheat cultivars. Cereal Chem. 82:633-638.

[Received March 30, 2008. Accepted November 12, 2008.] 